\title{
Extraction and Measurement the Activities of Cytosolic Phosphoenolpyruvate Carboxykinase (PEPCK) and Plastidic NADP-dependent Malic Enzyme (ME) on Tomato
}

(Solanum lycopersicum)

Sonia Osorio ${ }^{*}$, José G. Vallarino ${ }^{1}$, Marek Szecowka², Shai Ufaz ${ }^{3}$, Vered Tzin ${ }^{3}$, Ruthie Angelovici $^{3}$, Gad Galili ${ }^{3}$ and Alisdair R. Fernie ${ }^{4}$

\author{
1Department of Molecular Biology and Biochemistry, Instituto de Hortofruticultura Subtropical y \\ Mediterránea "La Mayora" - University of Malaga- Consejo Superior de Investigaciones \\ Científicas (IHSM-UMA-CSIC), Malaga, Spain; ${ }^{2}$ Central Metabolism Research Group, Max- \\ Planck-Institut für Molekulare Planzenphysiologie, Potsdam-Golm, Germany; ${ }^{3}$ Department of \\ Plant Sciences, Weizmann Institute of Science, Rehovot, Israel \\ *For correspondence: sosorio@uma.es
}

[Abstract] A recent study demonstrated that cytosolic phosphoenolpyruvate carboxykinase (PEPCK) and NADP-malic enzyme (NADP-ME) have an important role in malate metabolism during fruit ripening (Osorio et al., 2013). PEPCK catalyze the ATP-dependent decarboxylation of oxaloacetate (OAA) to phosphoenolpyruvate (PEP) and NADP-ME, the reversible conversion of malate and pyruvate. Here, we present the detailed protocols to measure PEPCK activity in carboxylation direction by following oxidation of NADH and to measure NADP-ME activity based upon the reduction of $\mathrm{NADP}^{+}$.

\section{Materials and Reagents}

\section{A. PEPCK activity}

1. Un-harvested plant tissues (how to freeze the tissue is explained in the procedure section)

2. Liquid $\mathrm{N}_{2}$

3. Ice

4. Bicine (Sigma-Aldrich, catalog number: B8660)

5. $\mathrm{KOH}$

6. EDTA (Sigma-Aldrich, catalog number: EDS-100G)

7. Poly (ethylene glycol) - 4000 (Sigma-Aldrich, catalog number: 81240)

8. Dithiothreitol (DTT) (Sigma-Aldrich, catalog number: 43815)

9. $\beta$-nicotinamide adenine dinucleotide reduced form (NADH) (Roche Diagnostics, catalog number: 10128015001) 
10. 4-(2-Hydroxyethyl)piperazine-1-ethanesulfonic acid, N-(2-Hydroxyethyl)piperazine-N'-(2ethanesulfonic acid) (HEPES) (Sigma-Aldrich, catalog number: H3375)

11. $\mathrm{KCl}$

12. $\mathrm{MnCl}_{2}$

13. Phosphoelnolpyryvate (PEP) (Bio Vectra, catalog number: 2552)

14. Adenosine 5'-diphosphate sodium salt (ADP) (Sigma-Aldrich, catalog number: A2754)

15. $\mathrm{KHCO}_{3}$

16. L-Malate dehydrogenase (Roche Diagnostics, catalog number: 10127248001)

17. Bradford stock solution (Bio-Rad Laboratories, catalog number, 500-0006)

18. Bovine serum albumin (BSA) (Sigma-Aldrich, catalog number: A2058)

19. Extraction buffer 1 (see Recipes)

20. Extraction buffer 2 (see Recipes)

21. Buffer 3 (see Recipes)

22. PEPCK assay mix 1 (see Recipes)

B. NADP-ME activity

1. Un-harvested plant tissues (how to freeze the tissue is explained in the procedure section)

2. Liquid $\mathrm{N}_{2}$

3. Ice

4. Tris-Base (United State Biological, catalog number: T8600)

5. $\mathrm{MnCl}_{2}$

6. EDTA (Sigma-Aldrich, catalog number: EDS-100G)

7. Glycerol (Sigma-Aldrich, catalog number: G5516)

8. 2-mercaptoethanol (Sigma-Aldrich, catalog number: M6250)

9. $\beta$-nicotinamide adenine dinucleotide phosphate $\left(\mathrm{NADP}^{+}\right)$(Roche Diagnostics, catalog number: 10128058001)

10. L-Malate (Sigma-Aldrich, catalog number: M1000)

11. Bradford stock solution (Bio-Rad Laboratories, catalog number, 500-0006)

12. Bovine serum albumin (BSA) (Sigma-Aldrich, catalog number: A2058)

13. Extraction buffer 4 (see Recipes)

14. NADP-ME assay mix 1 (see Recipes)

\section{Equipment}

1. Small mortar and pestle

2. $2 \mathrm{ml}$ and $1.5 \mathrm{ml}$ microfuge tubes 
3. Pipettes

4. Balance

5. $2 \mathrm{ml}$ centrifuge (Hettich Mikro 22R)

6. 96 well polystyrene microplate (flat bottom) (Corning, catalog number: 3300 )

7. A computer supported microplate spectrophotometer for kinetic (time-course) measurement mode (Elisa microplate-spetrophotometer) (BioTek Instruments, model: EL808)

\section{Procedure}

\section{A. Extraction for measuring PEPCK activity}

This protocol applies to extraction of PEPCKs from plant tissues.

1. Collect the sample and freeze immediately in liquid $\mathrm{N}_{2}$. Store at $-80^{\circ} \mathrm{C}$ until use.

2. Add small amount of liquid $\mathrm{N}_{2}$ and frozen sample into a mortar. Grind the tissue until the sample is a fine powder. Carefully add more liquid $\mathrm{N}_{2}$ if needed to keep frozen.

3. Weight $500 \mathrm{mg}$ of tissue into microfuge tube and add $900 \mu \mathrm{l}$ of extraction buffer 1 (EB1) (for fruit tissue the ratio of powered tissue/EB is $1: 1.8, \mathrm{w} / \mathrm{v}$. This ratio may need to be increased to $1: 3$ for leaf tissue).

4. Keep on ice while preparing all samples and vortex for $30 \mathrm{sec}$.

5. Centrifuge $15 \mathrm{~min}$ at $4{ }^{\circ} \mathrm{C}$ and $13,000 \times \mathrm{g}$. Remove $500 \mu \mathrm{l}$ supernatant (clarified extract) to a fresh microfuge tube and add $850 \mu$ of extraction buffer 2 (EB2), to give a final concentration of $35 \%$ PEG (mix well).

6. Incubate on ice for $10 \mathrm{~min}$ and centrifuge for $20 \mathrm{~min}$ at $13,000 \times \mathrm{g}$. The supernatant is discarded.

7. Re-suspend the pellet in $100 \mu \mathrm{l}$ of buffer 3 (B3) and keep on ice. Measure immediately PEPCK activity or the aliquots of clarified extracts can be snap frozen in liquid $\mathrm{N}_{2}$ and stored at $-80^{\circ} \mathrm{C}$ for future use.

\section{B. PEPCK activity}

The activity of PEPCK is measured in carboxylation direction by following oxidation of NADH at $340 \mathrm{~nm}$ at $25^{\circ} \mathrm{C}$. Briefly, a continuous assay is used in which OAA produced by PEPCK is immediately reduced to malate, and this is achieved by the inclusion of malate dehydrogenase. The oxidation of $\mathrm{NADH}$ by malate dehydrogenase is measured at $340 \mathrm{~nm}$ using a spectrophotometer.

1. Accurately pipette $2-10 \mu \mathrm{l}$ of clarified extract into a microplate well.

2. Use repeat pipetor to add $150 \mu \mathrm{I}$ PEPCK assay mix 1 to each well and immediately place in microplate spectrophotometer. Continuously monitor NADH oxidation to $\mathrm{NAD}^{+}$as a 
decline in absorbance at $340 \mathrm{~nm}\left(\mathrm{~A}_{340}\right)$, taking readings every $5-10 \mathrm{sec}$ for up to $5 \mathrm{~min}$ (the samples need to shake while reading).

3. Correct for background NADH oxidation by omitting PEP from the reaction mixture. Ensure that the decline in $\mathrm{A}_{340}$ (amount of $\mathrm{NADH}$ being oxidized; $\varepsilon 340=6,220 / \mathrm{M} / \mathrm{cm}$ ) is proportional to assay time and concentration of enzyme assayed. Dilution of clarified extract in extraction buffer may be necessary for samples containing abundant PEPCK activity.

Note: One international unit $(U)$ of enzyme activity is defined as the amount of enzyme resulting in the production of $1 \mu \mathrm{mol}$ of product per min at $25^{\circ} \mathrm{C}$. PEPCK activity in $(\mathrm{U} / \mathrm{ml}$ clarified extract $)=\left(\Delta A_{340} / \mathrm{min} \times\right.$ clarified extract dilution factor $) / 6.22$. Thus, if $3.0 \mu \mathrm{l}$ of clarified extract mixed with $150 \mu$ of PEPCK reaction mixture yields a $\triangle A_{340} /$ min of 0.2 at $340 \mathrm{~nm}$, then the PEPCK activity $=(0.2 \times 50) / 6.22 \mathrm{U} / \mathrm{ml}=1.6 \mathrm{U} / \mathrm{ml}$.

\section{Extraction for measuring NADP-ME activity}

This protocol applies to extraction of NADP-MEs from plant tissues.

1. Collect the sample and freeze immediately in liquid $\mathrm{N}_{2}$. Store at $-80^{\circ} \mathrm{C}$ until use.

2. Add small amount of liquid $\mathrm{N}_{2}$ and frozen sample into a mortar. Grind the tissue until the sample is a fine powder. Carefully add more liquid $\mathrm{N}_{2}$ if needed to keep frozen.

3. Weight $100 \mathrm{mg}$ of tissue into microfuge tube and add $200 \mu \mathrm{l}$ of extraction buffer 4 (EB4) (for fruit tissue the ratio of powered tissue/EB is $1: 2$, w/v. This ratio may need to be increased to 1:3 for leaf tissue).

4. Keep on ice while preparing all samples and vortex for $30 \mathrm{sec}$.

5. Centrifuge $10 \mathrm{~min}$ at $4{ }^{\circ} \mathrm{C}$ and $13,000 \times \mathrm{g}$. Transfer the supernatant to a fresh microfuge tube. Measure NADP-ME activity immediately or the aliquots of clarified extracts can be snap frozen in liquid $\mathrm{N}_{2}$ and stored at $-80{ }^{\circ} \mathrm{C}$ for future use.

D. NADP-ME activity

The activity of NADP-ME is based upon the reduction of NADP ${ }^{+}$at $340 \mathrm{~nm}$ at $25^{\circ} \mathrm{C}$. Briefly, a continuous assay is used in which malate is oxidized to pyruvate and $\mathrm{CO}_{2}$, and $\mathrm{NADP}^{+}$is reduced to NADPH. The reduction of $\mathrm{NADP}^{+}$by NADP-ME is measured at $340 \mathrm{~nm}$ using a spectrophotometer.

1. Accurately pipette 5-10 $\mu \mathrm{l}$ of clarified extract into a microplate well.

2. Use repeat pipetor to add $100 \mu \mathrm{I}$ NADP-ME assay mix 1 to each well and immediately place in microplate spectrophotometer. Continuously monitor $\mathrm{NADP}^{+}$reduction to $\mathrm{NADPH}$ as an increase in absorbance at $340 \mathrm{~nm}\left(\mathrm{~A}_{340}\right)$, taking readings every $5-10 \mathrm{sec}$ for up to $5 \mathrm{~min}$ (the samples need to shake while reading). 
3. Correct for background $\mathrm{NADP}^{+}$reduction by omitting L-malate from the reaction mixture. Ensure that the increase in $A_{340}$ is proportional to assay time and concentration of enzyme assayed. Dilution of clarified extract in extraction buffer may be necessary for samples containing abundant NADP-ME activity.

Note: One international unit $(U)$ of enzyme activity is defined as the amount of enzyme that catalyzes the formation of $1 \mu \mathrm{mol}$ of NADPH $\mathrm{min}^{-1}$ under the specified conditions. NADP-ME activity in $(\mathrm{U} / \mathrm{ml}$ clarified extract $)=\left(\Delta A_{340} / \mathrm{min} \times\right.$ clarified extract dilution factor)/6.22. Thus, if $2.0 \mu \mathrm{l}$ of clarified extract mixed with $100 \mu \mathrm{l}$ of NADP-ME reaction mixture yields a $\Delta A_{340} / \mathrm{min}$ of 1.5 at $340 \mathrm{~nm}$, then the NADP-ME activity $=(1.5 \times 50) / 6.22$ $\mathrm{U} / \mathrm{ml}=12.5 \mathrm{U} / \mathrm{ml}$.

E. Bradford assay of protein concentration

1. For preparing the BSA standard curve:

Make $1 \mathrm{ml}$ stock solution of $10 \mathrm{mg} \mathrm{BSA} / 200 \mathrm{ml}$ phosphate buffered saline (PBS) (pH 7.4) and prepare a duplicate standard curve, using template below:

\begin{tabular}{|c|c|c|c|}
\hline $\begin{array}{c}\text { Final } \\
\text { concentration } \\
\text { (ng/ } \mathbf{\mu l})\end{array}$ & $\begin{array}{c}\text { Vol. }(\boldsymbol{\mu l}) \mathrm{BSA} \text { stock } \\
\mathbf{( 0 . 0 5} \mathbf{~ m g / m l )}\end{array}$ & PBS $(\boldsymbol{\mu l})$ & $\begin{array}{c}\boldsymbol{\mu g} \\
\text { protein/well }\end{array}$ \\
\hline 0 & 0 & 200 & 0 \\
\hline 6.25 & 25 & 175 & 1.25 \\
\hline 12.5 & 50 & 150 & 2.5 \\
\hline 18.7 & 75 & 125 & 3.75 \\
\hline 25.0 & 100 & 100 & 5 \\
\hline
\end{tabular}

2. Pipette $50 \mu \mathrm{l}$ of aliquot supernatants (or its dilutions) or BSA standards to each well.

3. Add $130 \mu \mathrm{l}$ Bradford stock solution (see Materials and Reagents section) previously dissolved in distillate water (dilution 1/5).

4. Shake briefly and wait $5 \mathrm{~min}$. Determinate the OD at $595 \mathrm{~nm}$. Use slope and blank obtained from the calibration to determinate the protein concentration in each extracts.

\section{$\underline{\text { Recipes }}$}

1. Extraction buffer 1 (EB1, kept on ice)

$500 \mathrm{mM}$ Bicine- $\mathrm{KOH}$ (pH 9.0)

$200 \mathrm{mM} \mathrm{KCl}$

3 mM EDTA 
5\% (w/v) PEG-4000

$25 \mathrm{mM}$ DTT (add freshly every time before using it)

$0.4 \%$ BSA

2. Extraction buffer 2 (EB 2, kept on ice)

$500 \mathrm{mM}$ Bicine- $\mathrm{KOH}$ (pH 9.0)

3 mM EDTA

$55 \%$ (w/v) PEG-4000

$25 \mathrm{mM}$ DTT (add freshly every time before using it)

3. Buffer 3 (EB3, keep on ice)

$10 \mathrm{mM}$ Bicine- $\mathrm{KOH}$ ( $\mathrm{pH} 9.0$ )

$25 \mathrm{mM}$ DTT (add freshly every time before using it)

Note: EB1, EB2, and EB3 without DTT can be kept at $4{ }^{\circ} \mathrm{C}$ for few weeks.

4. PEPCK assay mix 1

$100 \mathrm{mM}$ Hepes-KOH (pH 6.8)

$100 \mathrm{mM} \mathrm{KCl}$

$0.14 \mathrm{mM}$ NADH

$25 \mathrm{mM}$ DTT (add freshly every time before using it)

$6 \mathrm{mM} \mathrm{MnCl}_{2}$

6 mM PEP

$1 \mathrm{mM}$ ADP

$90 \mathrm{mM} \mathrm{KHCO}_{3}$

$6 \mathrm{U} / \mathrm{ml}$ malate dehydrogenase

5. Extraction buffer 4 (EB4, kept on ice)

$100 \mathrm{mM}$ Tris- $\mathrm{HCl}(\mathrm{pH} 8.0)$

$5 \mathrm{mM} \mathrm{MgCl} 2$

2 mM EDTA

$10 \%(\mathrm{v} / \mathrm{v})$ glycerol

$10 \mathrm{mM}$ 2-mercaptoethanol

6. NADP-ME assay mix 1 (kept on ice)

$50 \mathrm{mM}$ Tris- $\mathrm{HCl}(\mathrm{pH} 8.0)$

$10 \mathrm{mM} \mathrm{MgCl}_{2}$

$0.5 \mathrm{mM} \mathrm{NADP}^{+}$

$10 \mathrm{mM}$ L-malate 


\section{Acknowledgments}

We acknowledge the excellent care of the plants by Helga Kulka (Max- Planck-Institut für Molekulare Planzenphysiologie) and Hanna Levanony (Weizmann Institute of Science). This protocol was adapted from Osorio et al. (2013).

\section{References}

1. Centeno, D. C., Osorio, S., Nunes-Nesi, A., Bertolo, A. L., Carneiro, R. T., Araujo, W. L., Steinhauser, M. C., Michalska, J., Rohrmann, J., Geigenberger, P., Oliver, S. N., Stitt, M., Carrari, F., Rose, J. K. and Fernie, A. R. (2011). Malate plays a crucial role in starch metabolism, ripening, and soluble solid content of tomato fruit and affects postharvest softening. Plant Cell 23(1): 162-184.

2. Osorio, S., Vallarino, J. G., Szecowka, M., Ufaz, S., Tzin, V., Angelovici, R., Galili, G. and Fernie, A. R. (2013). Alteration of the interconversion of pyruvate and malate in the plastid or cytosol of ripening tomato fruit invokes diverse consequences on sugar but similar effects on cellular organic acid, metabolism, and transitory starch accumulation. Plant Physiol 161(2): 628-643. 